\title{
Nasal NK/T-cell lymphoma: epidemiology and pathogenesis
}

\author{
Katsuyuki Aozasa $\cdot$ Tetsuya Takakuwa \\ Tadashi Hongyo $\cdot$ Woo-Ick Yang
}

Received: 17 October 2007/Accepted: 30 October 2007/Published online: 8 February 2008

(c) The Japanese Society of Hematology 2008

\begin{abstract}
Nasal NK/T-cell lymphoma (NKTCL) is an uncommon disease, but usually shows a highly aggressive clinical course. The disease is much more frequent in Asian and Latin American countries than in Western countries, and is universally associated with Epstein-Barr virus (EBV) infection. Analyses of gene mutations, especially p53 and c-KIT, revealed the different frequencies by district. Epidemiological studies revealed the changes of the disease frequency in Korea during the period from 19771989 to $1990-1996$. Case-control study showed that the exposure to pesticides and chemical solvents could be causative of NKTCL. Further studies including HLA antigen typing of patients is necessary to further clarify the disease mechanism.
\end{abstract}

Keywords Nasal lymphoma - NK/T-cell type · Epstein-Barr virus $\cdot$ p53 gene $\cdot$ c-KIT gene $\cdot$ Pesticide . Epidemiology

This study was supported in part by grants $(1639015,18014015)$ from the Ministry of Education, Culture, Sports, Science and Technology, Japan.

K. Aozasa ( $\square) \cdot$ T. Takakuwa

Department of Pathology (C3), Osaka University

Graduate School of Medicine, 2-2 Yamadaoka, Suita,

Osaka 565-0871, Japan

e-mail: aozasa@molpath.med.osaka-u.ac.jp

T. Hongyo

Department of Radiation Biology, Osaka University

Graduate School of Medicine, Osaka, Japan

W.-I. Yang

Department of Pathology, College of Medicine,

Yonsei University, Seoul, South Korea
Rapid destruction of the nose and face (midline) was firstly described by McBride in 1897 [1]. Macroscopically the lesions usually looked like necrotic granuloma and the patients showed aggressive and lethal course, therefore the term "lethal midline granuloma (LMG)" or "granuloma gangrenescens" were used for this condition. Later the term LMG is popularly used. It had became evident that the LMG is composed of three different types of histology, i.e. Wegener's granulomatosis (WG), polymorphic reticulosis (PR) or midline malignant reticulosis (MMR), and malignant lymphoma $[2,3]$. These diseases could be histologically differentiated from each other by taking clinical findings into account. WG is usually characterized by generalized necrotizing vasculitis involving both arteries and veins and the presence of glomerulitis [4]. Cancer and specific inflammation such as tuberculosis also cause a condition indistinguishable from LMG.

PR exhibits a polymorphous pattern of proliferation consisting of large atypical cells with mono- or multinucleus, small lymphocytes, plasma cells, benign-appearing macrophages, neutrophils and much less frequently eosinophils. PR had been considered as a variant of malignant lymphomas because the disease is frequently disseminated [2]. The nature of proliferating cells in PR had been controversial. Once the disease was termed as nasal T-cell lymphoma because the proliferating cells showed a positive immunoreactivity for polyclonal antibodies against $\mathrm{T}$ cells $[5,6]$. However, monoclonal rerrangement of the Tcell receptor genes was seldomly found in cases with "nasal T-cell lymphoma" [7]. Later Ng et al. [8] reported that the tumor cells showed a positive immunoreactivity for natural killer (NK) cell marker CD56. Subsequently it was shown that proliferating cells in PR had large granular lymphocyte morphology [9], which is a character of NK cells or cytotoxic T-lymphocytes. There have been 
Fig. 1 HE. Polymorphous nasal cavity. Large cells show CD3e, TIA-1, and CD56. ABC method, $\times 400$ pattern of proliferation in the positive immunoreactivity with

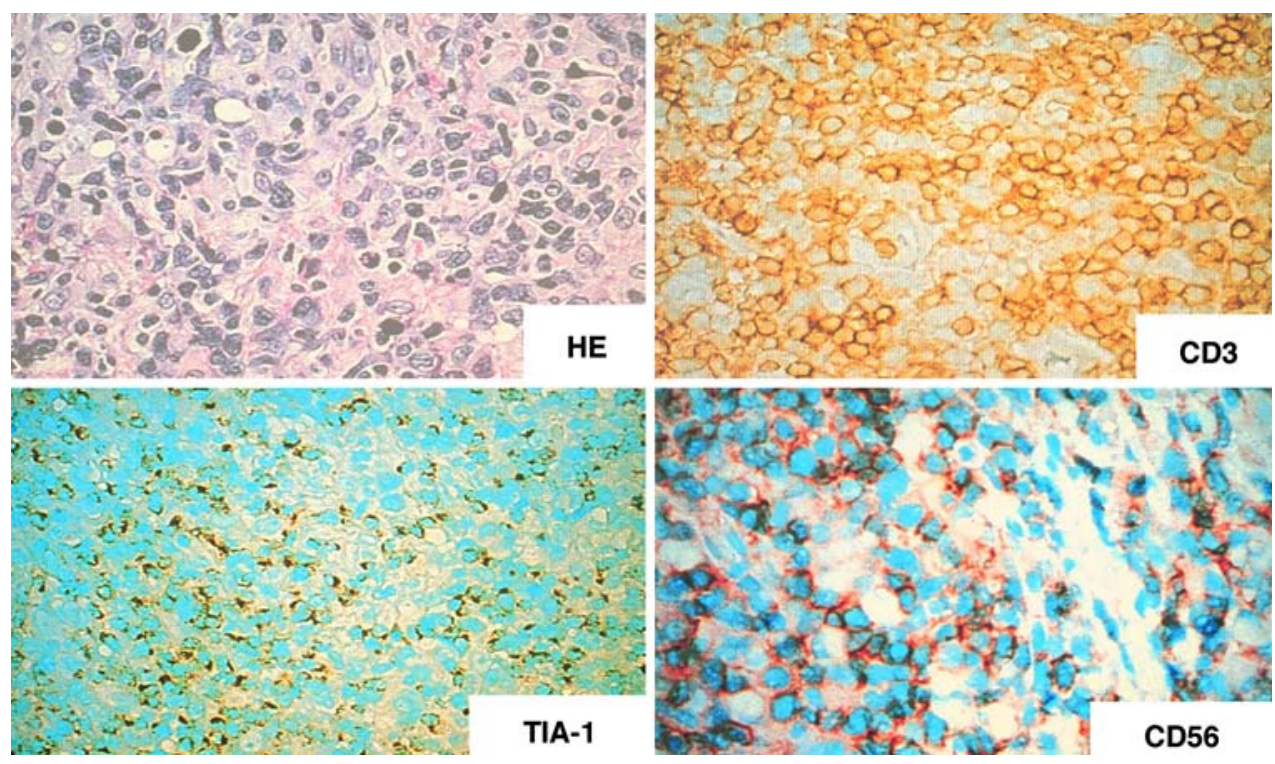

accumulating evidences that PR is a neoplasm of activated NK cells [10-13]: the proliferating cells usually show $\mathrm{CD} 2^{+}, \mathrm{CD} 56^{+}, \mathrm{CD} 3 \varepsilon^{+}, \mathrm{CD} 7^{-}, \mathrm{CD} 16^{-}$, cytotoxic granuleassociated proteins ${ }^{+}$and do not exhibit rearrangement of Tcell receptor or immunoglobulin genes (Fig. 1). Meanwhile rearrangement of $\mathrm{T}$-cell receptor genes was recorded in the rare cases of PR $[14,15]$. Although the upper respiratory tract, especially nasal region, is the common site of presentation, NK/T-cell lymphoma of nasal type may present in diverse extranodal sites such as gastrointestinal tract, skin, testis, liver, and spleen [16]. In the World Health Organization classification, NK/T-cell lymphoma encompasses the lymphomas involving nasal area and nonnasal area. Until present, there have been many review articles on the clinical, pathological, immunohistochemical, and immunogenetical aspects of NK/T-cell lymphomas involving upper respiratory tract. This review focuses on the epidemiology and molecular pathogenesis of nasal NK/ T-cell lymphoma (NLTCL).

\section{Association with Epstein-Barr virus (EBV)}

The association between EBV and human malignancies, including endemic Burkitt's lymphoma, Hodgkin lymphoma and non-Hodgkin's lymphoma (NHL) of either Bor T-immunophenotypes, has been reported. Etiological role of EBV for development of NKTCL was firstly reported in 1990 [17]. Subsequent study revealed the constant association of NKTCL with EBV in the world (Fig. 2) (Table 1) [18-23]. Sino-nasal lymphomas are immunophenotypically classified into NK/T-(CD56 $\left.{ }^{+}\right)$, T-, and B-cell type with distinctive clinical features [24]. CD56 positivity, therefore NKTCL, was closely associated

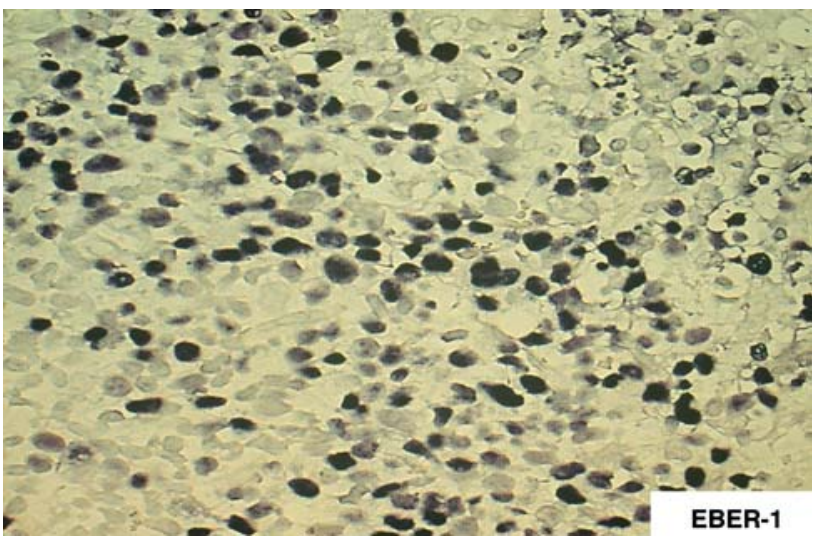

Fig. 2 In situ hybridization with EBER-1 probe reveals positive signals in the nucleus of proliferating cell

Table 1 EBV in nasal NK/T-cell lymphoma

\begin{tabular}{lllll}
\hline Source & Country & $\begin{array}{l}\text { EBV positive } \\
\text { rate }(\%)\end{array}$ & EBV subtype & $\begin{array}{l}\text { Expression } \\
\text { of latent }\end{array}$ \\
\hline$[18]^{\mathrm{a}}$ & France & $7 / 7(100)$ & NA & $7 / 7 \mathrm{LMP}+$ \\
{$[20]$} & China & $21 / 21(100)$ & NA & $5 / 21 \mathrm{LMP}-1+$ \\
{$[21]$} & Japan & $11 / 12(92)$ & $10 / 11$ typeA & $8 / 12 \mathrm{LMP}-1+$ \\
{$[22]$} & Korea & $15 / 16(94)$ & $15 / 15$ typeA & $7 / 15 \mathrm{LMP}-1+$ \\
{$[24]$} & Indonesia & $18 / 20(90)$ & NA & NA \\
\hline
\end{tabular}

$E B V$ Epstein-Barr virus, $L M P$ latent membrane protein, $N A$ not available

${ }^{\text {a }}$ Fresh tissue samples were used in the analyses

with EBV positivity among sino-nasal lymphomas [22]. EBV could be subtyped based on the difference in sequence of EBNA2 region, i.e. type A and type B [25]. Almost all of the NKTCL in Korea and Japan had type A 
EBV, which is identical with the previous literature reporting that most cases of EBV-associated malignancies of immunocompetent patients in Asia had type A EBV [26]. Predominance of type A EBV was also found in NKTCL in Malaysia [27], indicating the predominance of type A EBV in NKTCL in Asia. Several studies indicated the occurrence of type B EBV in lymphoma of immunocompromised patients [28]. Borisch et al. [29] reported that three of six cases of NKTCL in Switzerland had type B EBV, although no findings suggestive of immunodeficiency were found in these patients. These findings suggest a geographic difference in the distribution of EBV subtype in the NKTCL.

As shown in Table 1, the proliferating cells in NKTCL frequently express latent membrane protein (LMP) as revealed by immunohistochemistry. Latent infection gene products of EBV, EBNA-2 and LMP-1, serve as target antigens for the elimination of EBV infected cells by host cytotoxic T-lymphocytes (CTL) [30]. Shen et al. [31] showed that NKTCL cells are able to provide target epitopes of EBV for CTL. In immunocompromised hosts, proliferating cells expressing EBNA-2 and LMP-1 can escape from immune surveillance by the host CTL, which might result in the development of malignant lymphomas [32]. However, systemic immunosuppression is not noted in patients with NKTCL, thus suggesting an unknown underlying mechanism for escape of LMP-1-expressing tumor cells from the CTL. Several mechanisms such as downregulation of the immunogenic EBV nuclear antigens and preferential selection of the deletion genotype of LMP1 was reported by Chiang et al. [33, 34] and expression of IL-10, an immunosuppressive cytokine, was reported by Shen et al. [31]. The cells expressing viral antigens are eliminated primarily by CTL in a MHC-class-I-restricted manner [35]. Two CTL-epitopes were identified in LMP-1 that are possibly pan $\mathrm{A}^{* 02}$-restricted [36]. It is possible that NKTCL patients show lower frequencies of $A * 02$ allele compared with those in the normal population. Indeed high-resolution genetic typing revealed significantly lower frequency of HLA-A*0201 in NKTCL than in normal population [37]. These findings suggest that HLA$A * 0201-$ restricted CTL responses may function in vivo to suppress the development of NKTCL, or in other words, role of EBV for NKTCL development.

\section{Genetical changes}

Lymphoma arises from clonal expansion of lymphoid cells that are transformed by the accumulation of genetic lesions affecting oncogenes and tumor suppressor genes. In general, amount of samples from NKTCL lesions available for genetical analyses is small, and samples usually contain massive necrotic areas. Therefore information for genetical changes in NKTCL has been relatively limited until present.

\subsection{Alterations of tumor suppressor genes and oncogenes}

Polymerase chain reaction (PCR) - single strand conformation polymorphism (SSCP) followed by direct sequence method was employed for analyses of gene alterations in NKTCL. The genes analyzed by this method were p53, kras, c-kit, and $\beta$-catenin on the NKTCL cases from Asian countries [38-42] and Mexico [43]. p53 is a well-known tumor suppressor gene that causes cells with damaged DNA to arrest at the G1 phase of cell cycle or stimulating expression of the BAX gene, the protein that promotes apoptosis [44]. In a wide variety of human cancers, p53 gene mutations have been detected mainly in exon 5 through 8 [45]. K-RAS, c-KIT, and $\beta$-catenin genes are oncogenes. Greenblatt et al. [46] identified 50 studies in which sequencing of the entire coding region of p53 had been reported. Of the 560 mutations reported in those papers, $87 \%$ were found in exons $5-8$, and most of the others were in exon $4(8 \%)$. In the studies for NKTCL in Asia, exons 4-8 or exons 5-8 were examined in one institute (Table 2). The frequency of p53 mutations was
Table 2 p53 mutations in nasal NK/T-cell lymphoma

\begin{tabular}{lllll}
\hline & $\begin{array}{l}\text { Number } \\
\text { of cases }\end{array}$ & $\begin{array}{l}\text { Exons } \\
\text { examined }\end{array}$ & $\begin{array}{l}\text { Frequency } \\
\text { of mutations (\%) }\end{array}$ & $\begin{array}{l}\text { Predominance of } \\
\text { transition } \\
\text { mutation }\end{array}$ \\
\hline Asia & & & & \\
Japan [41] & 58 & $4-8$ & $62 \%$ & yes \\
Korea [41] & 42 & $4-8$ & $31 \%$ & yes \\
China & & & & yes \\
Beijing, Chengdu [38] & 42 & $5-8$ & $48 \%$ & yes \\
Shenyang [40] & 20 & $4-8$ & $40 \%$ & yes \\
Indonesia [42] & 27 & $4-8$ & $63 \%$ & no \\
Mexico [43] & 21 & $5-8$ & $24 \%$ & \\
\hline
\end{tabular}


various by district: high in Japan and Indonesia and low in Mexico, Korea, and Shenyang. Shenyang situates at north China, which is adjacent to the Korean peninsula, suggesting that environmental and genetical factors might generate the differences in frequency. Transitions (G:C to A:T) were the predominant pattern of mutations except for Mexico, in which number of cases with mutations was only five [43], thus the data from Mexico seemed to be not conclusive. Predominance of transition mutations suggests that some "endogenous" mutagens act in lymphomagenesis. The transition pattern of p53 mutations is known to be more susceptible to spontaneous genetic instability than transversion. While genetic instability as revealed by widespread microsatellite instability was not found in the cases with NKTCL [47].

Quintanilla-Martinez et al. reported the association of p53 overexpression with poor prognosis, and p53 mutations with large cell morphology and advanced stage [43, 48]. However these findings were not confirmed by other studies. [15, 38]

The c-KIT proto-oncogene encodes a receptor tyrosine kinase, which is involved in normal hematopoiesis, gametogenesis, and melanogenesis via the c-kit receptorligand system. [49]. Because the development of acute leukemia or malignant lymphoma was reported in transgenic mice expressing KIT $[8,14,50]$, NKTCL in Asian countries was examined for the c-kit gene mutations [41]. Frequency of c-kit mutations was significantly higher in China (Beijing, Chengdu) (10 of 14 cases: 71.4\%) [39] than in Japan (9 of 58 cases: 15.5\%) [41], Korea (5 of 42 cases:11.9\%) [41], northeast China (Shenyang) (2 of 20 cases:10\%) [40], and Indonesia (3 of 27 cases :11.1\%) [42]. These findings suggest that location-specific differences in etiological factors cause specific mutations in c-kit gene.

\subsection{FAS Gene Mutations}

Fas (Apo-1/CD95) is a $45 \mathrm{kDa}$ membrane protein belonging to the tumor necrosis factor receptor family, and mediates programmed cell death (apoptosis) through binding of FAS ligand (Fas L) [51]. Fas consists of 325 amino acids with a single transmembrane domain, including signal peptide. The 80-amino acid portion in the cytoplasm, designated as a death signaling domain, is essential for the apoptotic signal transduction. FAS gene mutations were reported in about $10 \%$ cases with sporadic non-Hodgkin's lymphoma [52]. NKTCL frequently coexpress FAS and FAS ligand (Fas L), but the tumor cells seldom undergo apoptosis. Some mechanisms for resistance to FAS/FAS L - induced apoptosis might work in the development of NKTCL, thus FAS gene mutations could be one of the mechanisms. Two reports support this notion:
NKTCL cells in 9 of $15(60 \%)$ cases [53] and 7 of 14 $(50 \%)$ cases [54] showed mutations of FAS gene. Mouse Tcell lymphoma cells transfected with mutated FAS genes were resistant to apoptosis (Fig. 3, Fig. 4) [54], indicating the mutations to be loss of function mutation. These findings suggest that accumulation of lymphoid cells with FAS mutations provides a basis for the development of NKTCL.

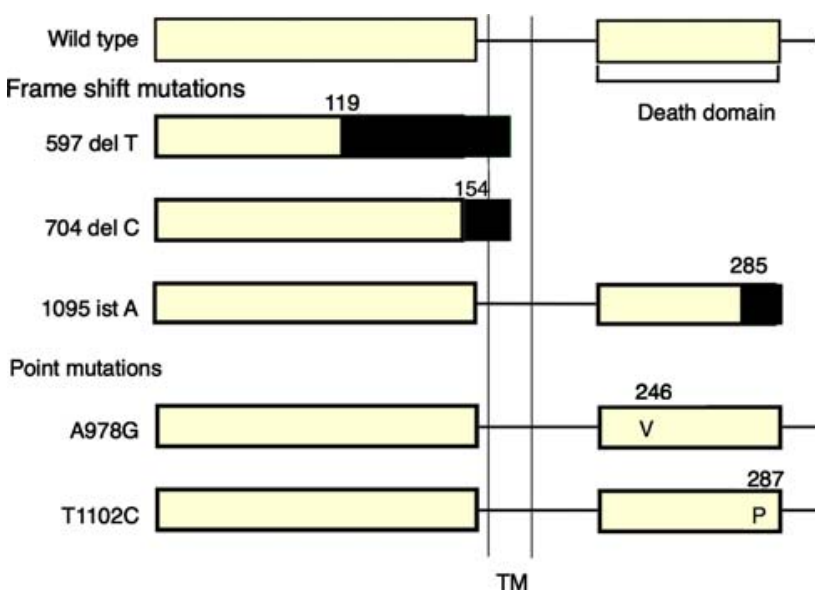

Fig. 3 Summary of the $F A S$ gene mutations found in patients with nasal NKTCL. The shaded rectangles at the $\mathrm{COOH}$-terminus of the protein represents the small peptide added because of the frameshift in the gene encoding FAS.TM: transmembrane domain

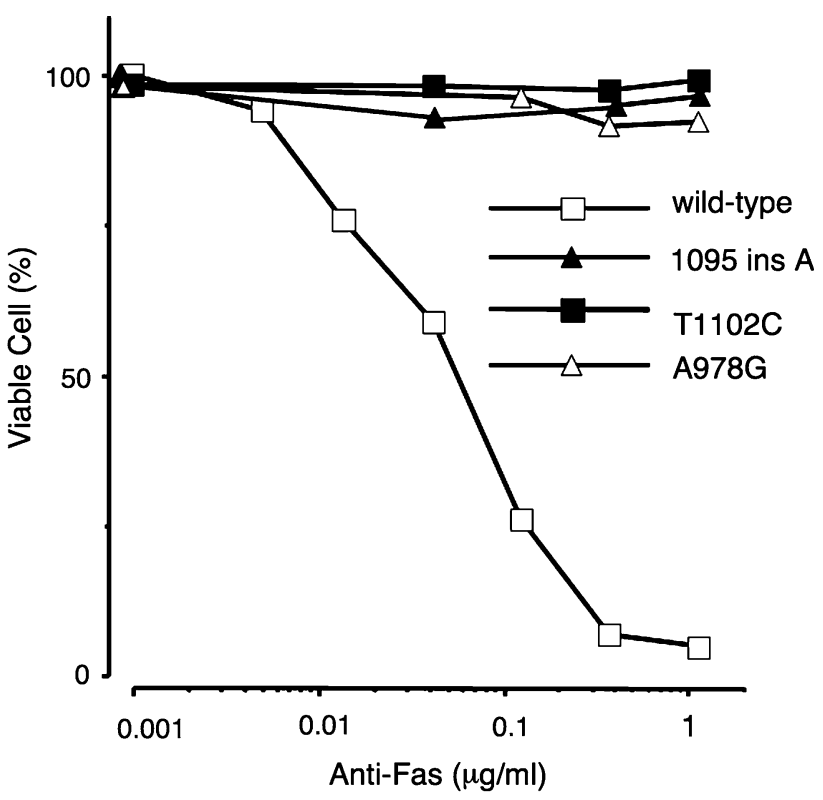

Fig. 4 The mouse WR19L cell line expressing recombinant human FAS protein with (T1102C, A978G, 1095 ins A) or without (wild type) mutations were incubated with various concentrations of antiFAS antibody at $37.0^{\circ} \mathrm{C}$ for $16 \mathrm{~h}$. Clones expressing FAS receptor with any mutations (A978G, 1095 ins A, T1102C) were resistant to apoptosis induced by the anti-FAS antibody 
Table 3 Frequency of lethal midline granuloma in Japan, Korea (Seoul), and China (Shanghai)

\begin{tabular}{|c|c|c|c|c|}
\hline \multirow[t]{2}{*}{ Disease } & \multicolumn{4}{|c|}{ Number of patients (frequency per 100,000 ENT patients) } \\
\hline & $\begin{array}{l}\text { Japan other than } \\
\text { Okinawa (1965-1986) }\end{array}$ & $\begin{array}{l}\text { Okinawa } \\
(1973-1991)\end{array}$ & $\begin{array}{l}\text { Seoul } \\
(1979-1989)\end{array}$ & $\begin{array}{l}\text { Shanghai } \\
(1979-1990)\end{array}$ \\
\hline Wegener's granulomatosis & $64(4)$ & $1(3)$ & $0(0)$ & $1(4)$ \\
\hline Polymorphic reticulosis & $114(8)$ & $9(27.4)$ & $56(40.8)$ & $73(9.8)$ \\
\hline Malignant lymphoma & $82(6)$ & $11(33.5)$ & $15(10.9)$ & $54(7.2)$ \\
\hline Others & $42(3)$ & $1(3)$ & $6(4.4)$ & $0(0)$ \\
\hline Total & $302(21)$ & $22(69.9)$ & $77(56)$ & $128(17)$ \\
\hline
\end{tabular}

\subsection{Others}

Various cytogenetic alterations have been reported, of which deletions of $6 \mathrm{q}$ are the common [55].

\section{Epidemiological features}

It had been reported that NKTCL seemed to be relatively common among non-Hodgkin's lymphoma in Hong Kong [56-58]: malignant lymphomas affecting nose and nasopharyngeal region constituted $7.2 \%$ of extranodal lymphomas [56] and 45 of 70 cases with malignant lymphomas in the nose, nasopharynx, and larynx had PR morphology [57]. This disease is occasionally encountered in the hospitals in Japan $[5,59,60]$. When one of the authors (KA) visited the USA in 1987, he noticed that the disease was quite rare in the USA, but they had consultation cases from Peru. Because Japanese and a part of Peruvian belong to Mongolian ethnic group, it was postulated that the Mongolian group might be much more frequently affected by this disease. Then they started to examine the frequency of NKTCL in Japan, Korea (Seoul), and China (Shanghai) during the period from 1987 to 1993 . The results are summarized in Table 3 [6163], in which the frequency of each disease constituting LMG is shown as the frequency per 100,000 patients who visited the Ear-Nose-Throat (ENT) clinic in 37 university hospitals in Japan, Ryukyu University Hospital in Okinawa, Japan, Yonsei University Hospital in Seoul, and Shanghai Medical University Hospital. All of the histological sections were reviewed by one of the authors (KA). Frequency of PR ranged from 8 to 40.8. That in the Institute of Laryngology and Otology, London (19661987) was four, showing two to ten times higher frequencies of the PR in the east Asian countries [61]. The disease is rare in the USA [64] and Europe [65]. The patients with NKTCL seem to be clustered also in Latin American countries and Indonesia [66, 67]. Information from other parts of the world such as Africa, the Middle and Near East, and Rusia is helpful to elucidate the etiology of this disease.
At the late 1990s, otorhinolaryngologists in both Korea and Japan had the impression that the frequency of PR appeared to be decreasing. Then the changes in frequency of PR with time among cases from Seoul and 59 university hospitals in Japan were examined [68]: the frequency rate of PR per 100,000 outpatients of ENT clinics in Seoul decreased from 40 to 20 between the periods of 1977-1989 and 1990-1996. However, there were no significant changes in Japan during the period studies.

\subsection{Life-style and environmental factors}

Epidemiological studies have revealed that the NKTCL occurs much more frequently in Asian countries than in Western countries and it is closely associated with EBV infection. There are differences in frequencies of p53 and c-kit gene mutations among patients with NKTCL in Japan, China, and Korea. Recently the first case of familial NKTCL affecting a father and one of his six children was reported [69]. They used large amounts of pesticide in a green house. An increase in the risk of developing NHL among individuals exposed to pesticides was reported [70, 71]. In addition, a correlation of exposure to certain pesticides and organochlorines with increased titers of antibodies to EBV was reported [72]. All these findings might suggest a causative role for some genetical, environmental and life style factors in the development of NKTCL. Therefore, the epidemiological study to elucidate whether socioenvironmental ambient factors contribute to the development of NKTCL was conducted as a collaborative study of Japan, Korea and China (Table 4) [73]. The odd ratio (OR) of NKTCL was 4.15 (95\% confidence interval (CI), 1.74-9.37) for farmers, 2.81 (CI 1.49-5.29) for producers of crops, and 4.01 (CI 1.99-8.09) for pesticide users. The ORs for crop producers, who minimized their exposure to pesticides by using gloves and glasses, and sprinkling downwind at the time of pesticide use, were 3.30 (CI 1.28-8.54), 1.18 (CI 0.11-12.13), and 2.20 (CI 0.88-5.53), respectively, which were lower than those for producers who did not take these precautions. Exposures to pesticides and chemical solvents could be causative factors 
Table 4 Risk of nasal NK/Tcell lymphoma in relation to cultivation of crops and pesticide use
CI confidence interval

a Adjusted for age $(<40,40-59$, $>60$ ), sex (male/female) and country (Japan, Korea and China)

\begin{tabular}{|c|c|c|c|c|c|}
\hline & \multirow{2}{*}{$\begin{array}{l}\text { Odds ration } \\
(\mathrm{OR})^{\mathrm{a}}\end{array}$} & \multirow{2}{*}{$\begin{array}{l}\text { Number of } \\
\text { cases } N=88\end{array}$} & \multirow{2}{*}{$\begin{array}{l}\text { Number of } \\
\text { controls } N=305\end{array}$} & \multicolumn{2}{|c|}{$95 \% \mathrm{CI}$} \\
\hline & & & & Lower & Upper \\
\hline \multicolumn{6}{|l|}{ Cultivation of crops } \\
\hline At present & 2.81 & 27 & 36 & 1.49 & 5.29 \\
\hline More than 5 years & 5.08 & 24 & 19 & 2.47 & 10.43 \\
\hline \multicolumn{6}{|l|}{ Pesticides } \\
\hline Users & 4.01 & 23 & 23 & 1.99 & 8.09 \\
\hline \multicolumn{6}{|l|}{ Type of pesticide } \\
\hline Herbicide & 3.17 & 13 & 16 & 1.36 & 7.38 \\
\hline Insecticide & 3.45 & 20 & 21 & 1.67 & 7.13 \\
\hline Fungicide & 6.05 & 10 & 6 & 1.98 & 18.46 \\
\hline \multicolumn{6}{|l|}{ Precautions } \\
\hline Gloves used & 3.30 & 10 & 11 & 1.28 & 8.54 \\
\hline Gloves not used & 4.76 & 13 & 12 & 1.93 & 11.72 \\
\hline Mask used & 5.44 & 14 & 10 & 2.20 & 13.47 \\
\hline Mask not used & 2.82 & 9 & 13 & 1.08 & 7.37 \\
\hline Glasses used & 1.18 & 1 & 3 & 0.11 & 12.13 \\
\hline Glasses not used & 4.52 & 22 & 20 & 2.17 & 9.42 \\
\hline Sprinkling downward attended & 2.20 & 9 & 16 & 0.88 & 5.53 \\
\hline Sprinkling downward not attended & 8.45 & 14 & 7 & 3.01 & 23.70 \\
\hline
\end{tabular}

for NKTCL. Previous studies showed the increased risk of NHL in individuals using pesticides, especially phenoxyacetic acid-type herbicides [74]. Association of pesticides with risk of developing $t(14 ; 18)$ positive-NHL, but not $t(14 ; 18)$ negative-NHL, was reported [75].

\section{Conclusions}

Clinical course of patients with NKTCL is usually highly aggressive. Therefore clarification of risk factors for disease development is especially important to establish a strategy for disease prevention. Because EBV infection and pesticides could be risk factors for NKTCL, investigation on effects of pesticides for EBV activation is needed. Employment of the similar kind of the epidemiological study is desirable in other areas than East Asia. Patients with NKTCL cluster in Asia and Latin American countries, therefore some genetical factors might be involved in the disease development. Further studies including HLA antigen typing of patients is important to further clarify the mechanism for disease development.

\section{References}

1. McBride P. Photographs of a case of rapid destruction of the nose \& face. Laryngol. 1987;12:64-6.

2. Eichel BS, Harrison EGJ, Devine KD, Scanlon PW, Brown HA. Primary lymphoma of the nose including relationship to lethal midline graanuloma. Am J Surg. 1966;112:597-605.
3. Kassel S, Echevaria RA, Guzzo FP. Midline malignant reticulosis (so-called lethal midline granuloma). Cancer. 1969;23:920 35.

4. Godman GC, Churg J. Wegener's granulomatosis, pathology and review of the literature. Arch Pathol. 1954;58:533-53.

5. Ishii Y, Yamanaka N, Ogawa K, Yoshida Y, Takami T, Matsuura A, et al. Nasal T-cell lymphoma as a type of so-called "lethal midline granuloma". Cancer. 1982;50:2336-44.

6. Chan KC, Ng CS, Lau WH, Lo ST. Most nasal/ nasopharyngeal lymphomas are peripheral T-cell neoplasms. Am J Surg Pathol. 1987;11:418-29.

7. Weiss LM, Picker LJ, Grogan TM, Warnke RA, Sklar J. Absence of clonal beta and gamma T-cell receptor gene rarrangements in a subset of peripheral T-cell lymphomas. Am J Pathol. 1988;130: 436-42.

8. Ng CS, Chan JKC, Lo STH. Expression of natural-killer-cell markers in non-Hodgkin's lymphomas. Hum Pathol. 1987;18:1257-62.

9. Aozasa K, Ohsawa M, Tomita Y, Tagawa S, Yamamura T. Polymorphic reticulosis is a neoplasm of large granular lymphocytes with $\mathrm{CD}^{+}$phenotype. Cancer. 1995;75:894-901.

10. Emile JF, Bouland ML, Maioun C, Kanavaros P, Petrella T, Delfau-Larue $\mathrm{MH}$, et al. $\mathrm{CD}^{-} \mathrm{CD}^{+} 6^{+} \mathrm{T}$-cell receptor silent peripheral T-cell lymphomas are natural killer cell lymphomas. Blood. 1996;87:1466-73.

11. Suzumiya J, Takeshita M, Kimura N, Kikuchi M, Uchida T, Hisano S, et al. Expression of adult and fetal natural killer cell markers in sinonasal lymphomas. Blood. 1994;83:2255-60.

12. Ohsawa M, Nakatsuka S, Kanno H, Miwa H, Kojya S, Harabuchi $\mathrm{Y}$, et al. Immunophenotypic and genotypic characterization of nasal lymphoma with polymorphic reticulosis morphology. Int $\mathrm{J}$ Cancer. 1999;81:865-70.

13. Jaffe ES, Harris NL, Stein H, Vardiman JW. Pathology and Genetics of Tumors of Haemapoietic and Lymphoid Tissues. Lyon, France: IARC Press, 2001.

14. Kluin PM, Feller A, Gaulard P, Jaffe ES, Meijer CJLM, MullerHermelink HK, et al. Peripheral T/NK-cell lymphoma: a report of 
IXth workshop of the European Association for Hematopathology. Histopathology. 2001;38:250-70.

15. Ng SB, Lai KW, Murugana S, Lee KM, Loong SL, Fook-Chong $\mathrm{S}$, et al. Nasal type extranodal natural killer/T-cell lymphomas; A clinicopathologic and genotypic study of 42 cases in Singapore. Mod Pathol. 2004;17:1097-107.

16. Chan JKC, Sin VC, Wong KF, Ng CS, Tsang WY, Chan CH, et al. Nonnasal lymphomas expressing the natural killer cell marker CD56: a clinicopathologic study of 49 cases of uncommon aggressive neoplasm. Blood. 1997;89:4501-13.

17. Harabuchi Y, Yamanaka N, Kataura A, Imai S, Kinoshita T, Mizuno F, et al. Epstein-Barr virus in nasal T-cell lymphomas in patients with lethal midline granuloma. Lancet. 1990;335:12830 .

18. Kanavaros P, Lescs MC, Briere J, Divine M, Galateau F, Joab I, et al. Nasal T-cell lymphoma: a clinicopathologic entity associated with peculiar phenotype and with Epstein-Barr virus. Blood. 1993;81:2688-95.

19. Mishima K, Horiuchi K, Kojya S, Takahashi H, Ohsawa M, Aozasa K. Epstein-Barr virus in patients with polymorphic reticulosis (lethal midline granuloma) from China and Japan. Cancer. 1994;73:3041-6.

20. Chan JKC,Yip TTC, Tsang WYW, Ng CS, Lau WH, Poon YF, et al. Detection of Epstein-Barr viral RNA in malignant lymphomas of the upper aerodigestive tract. Am J Surg Pathol. 1994;18:938-46.

21. Tomita Y, Ohsawa M, Mishiro Y, Kubo T, Maeshiro S, Kojya S, et al. The presence and subtype of Epstein-Barr virus in B and $\mathrm{T}$ cell lymphomas of the sino-nasal region from the Osaka and Okinawa districts of Japan. Lab Invest. 1995;73:190-6.

22. Tomita Y, Ohsawa M, Mishiro Y, Hashimoto M, Yang WI, Kim GE, et al. Epstein-Barr virus in lymphoproliferative diseases in the sino-nasal region: close association with $\mathrm{CD}^{+} 6^{+}$immunophenotype and polymorphic reticulosis morphology. Int J Cancer. 1997;70:9-13.

23. Hardjolukito E, Kurniawan AN, Kodairiah R, Ham MF, Luo WJ, Nakatsuka S, et al. Sinonasal lymphomas in Indonesia; Immunophenotype and Epstein-Barr virus association. Med J Indonesia. 2004;13:71-6.

24. Cheung MM, Chan JK, Lau WH, Foo W, Chan PT, Ng CS, et al. Primary non-Hodgkin's lymphoma of the nose and nasopharynx : clinical features, tumor immunophenotype, and treatment outcome in 113 patients. J Clin Oncol. 1998;16:70-7.

25. Dambaugh T, Hennessy K, Chamnankit L, Kieff E. U2 region of Epstein-Barr virus DNA may encode Epstein-Barr virus nuclear antigen 2. Proc Natl Acad Sci USA. 1984;81:7632-6.

26. Chen X, Pepper S, De V, Arrand JR. Prevalence of A and B types of Epstein-Barr virus DNA in nasopharyngeal carcinoma biopsies from South China. J Gen Virol. 1992;73:463-6.

27. Peh SC, Sardves K, Pallesen G. Epstein-Barr virus (EBV) in Malaysian upper-aerodigestive-tract lymphoma: incidence and subtype. Int J Cancer. 1995;61:327-32.

28. Boyle MJ, Sewell WA, Sculley TB, Apolloni A, Turner JJ, Swanson CE, et al. Subtypes of Epstein-Barr virus in human immunodeficiency virus-associated lymphohma. Blood. 1991;78:3004-11.

29. Borisch B, Henning I, Laeng RH, Waelti ER, Kraft R, Laissue J. Association of the subtype 2 of the Epstein-Barr virus with T-cell non-Hodgkin's lymphoma of the midline granuloma type. Blood. 1993;82:858-64.

30. Rickinson AB, Murray RJ, Brooks J, Griffin H, Moss DJ, Masucci MG. T cell recognition of Epstein-Barr virus associated lymphomas. Cancer Surv. 1992;13:53-80.

31. Shen L, Chiang AK, Liu WP, Li GD, Liang RH, Srivastava G. Expression of HLA class I, beta(2)-microglobulin, TAP 1 and IL10 in Epstein-Barr virus-associated nasal NK/T-cell lymphoma: implications for tumor immune escape mechanism. Int J Cancer. 2001;92:692-6.

32. Yong L, Alfieri C, Hennessy K, Evans H, Ohara C, Anderson KC, et al. Expression of Epstein-Barr virus transformation-associated genes in tissues of patients with EBV lymphoproliferative diseases. N Engl J Med. 1989; 321:1080-5.

33. Chiang AK, Tao Q, Srivastava G, Ho FC. Nasal NK-and T-cell lymphomas share the same type of Epstein-Barr virus latency as nasopharyngeal carcinoma and Hodgkin's disease. Int J Cancer. 1996;68:285-90.

34. Chiang AK, Wong KY, Liang AC, Srivastava G. Comparative analysis of Epstein-Barr virus gene polymorphism in nasal T/ NK-cell lymphomas and normal nasal tissues: implications on virus strain selection in malignancy. Int J Cancer. 1999;80:35664.

35. Rickinson AB, Moss DJ. Human cytotoxic $\mathrm{T}$ lymphocyte responses to Epstein-Barr virus infection. Ann Rev Immunol. 1997; 15:405-31.

36. Khanna R, Burrows SR, Nicholls J, Poulsen LM. Identification of cytotoxic $\mathrm{T}$ cell epitopes within Epstein-Barr virus (EBV) oncogene latent membrane protein 1 (LMP1): evidence for HLA A2 subtype restricted immune recognition of EBV-infected cells by LMP1-specific cytoxic $\mathrm{T}$ lymphocytes. Eur J Immunol. 1998;28:451-8.

37. Kanno H, Kojya S, Li T, Ohsawa M, Nakatsuka S, Miyaguchi M, et al. Low frequency of HLA-A*0201 allele in patients with Epstein-Barr virus-positive nasal lymphomas with polymorphic reiculosis morphology. Int J Cancer. 2000;87:195-9.

38. Li T, Hongyo T, Syaifudin M, Nomura T, Dong Z, Shingu N, et al. Mutations of the p53 gene in nasal NK/T-cell lymphoma. Lab Invest. 2000;80:493-9.

39. Hongyo T, Li T, Syaifudin M, Baskar R, Ikeda H, Kanakura Y, et al. Specific c-kit mutations in sinonasal natural killer/T-cell lymphoma in China and Japan. Cancer Res. 2000;60:2345-7.

40. Hoshida Y, Hongyo T, Jia XS, He Y, Hasui K, Dong Z, et al. Analysis of $\mathrm{p} 53$, k-ras, c-kit, and $\beta$-catenin gene mutatuins in sinonasal NK/T cell lymphoma in northeast district of China. Cancer Sci. 2003;94:297-301.

41. Hongyo T, Hoshida T, Nakatsuka S, Syaifudin M, Kojya S, Yang WI, et al. p53, k-ras, and $\beta$-catenin gene mutations in sinonasal NK/T-cell lymphoma in Korea and Japan. Oncol Rep. 2005; 13:267-71.

42. Kurniawan AN, Hongyo T, Hardjolukito ESR, Ham MF, Takakuwa T, Kodairiah R, et al. Gene mutation analysis of sinonasal lymphoma in Indonesia. Oncol Rep. 2006;15:1257-63.

43. Quintanilla-Martinez L, Kremer M, Keller G, Nathrath M, Gamboa-Dominguez A, Meneses A, et al. p53 mutations in nasal natural killer/T-cell lymphoma from Mexico: association with large ccell morphology and advanced disease. Am J Pathol. 2001;159:2095-105.

44. Levine AJ, Momand J, Finley CA. The p53 tumor suppressor gene. Nature. 1991;351:453-6.

45. Hollstein M, Sidransky D, Vogelstein B, Harris SR. p53 mutation in human cancers. Science. 1991;253:49-53.

46. Greenblatt MS, Benett WP, Hollstein M, Harris CC. Mutations in the p53 tumor suppressor gene: clues to cancer etiology and molecular pathogenesis. Cancer Res. 1994;54:4855-78.

47. Takakuwa T, Li T, Kanno H, Nakatsuka S, Aozasa K. No evidence of replication error phenotype in nasal NK/T-cell lymphoma. Int J Cancer. 1999;84:623.

48. Quintanilla-Martinez L, Franklin JL, Guerrero J, Krenacs L, Naresh KN, Rama-Rao C, et al. Histological and immunophenotypic profile of nasal NK/T-cell lymphomas from Peru: higher prevalence of p53 overexpression. Hum Pathol. 1999;30:849-55.

49. Williams DE, de Vries P, Namen AE, Widmer MB, Lyman SD. The steel factor. Dev Biol. 1992;151:368-76. 
50. Kitayama H, Tsujimura T, Matsumura I, Oritani K, Ikeda K, Ishikawa J, et al. Neoplastic transformation of normal hematopoietic cells by constitutively activating mutations of c-kit receptor tyrosine kinase. Blood. 1996;88:995-1004.

51. Suda T, Takahashi T, Golstein P, Nagata S. Molecular cloning and expression of the Fas ligand, a novel member of the tumor necrosis factor family. Cell. 1993;75:1169-78.

52. Gronbaek K, Straten PT, Ralfkier E, Ahrenkiel V, Andersen MK, Hansen NE, et al. Somatic Fas mutations in non-Hodgkin's lymphoma: association with extranodal disease and autoimmunity. Blood. 1998;92:3018-24.

53. Shen L, Liang ACT, Lu L, Au WY, Kwong YL, Liang RHS, et al. Frequent delection of Fas gene sequences encoding death and transmembrane domains in nasal natural killer/T-cell lymphoma. Am J Pathol. 2002;161:2123-31.

54. Takakuwa T, Dong Z, Nakatsuka S, Kojya S, Harabuchi Y, Yang Wl, et al. Frequent mutation of Fas gene in nasal NK/T cell lymphoma. Oncogene. 2002;21:4702-5.

55. Sun HS, Su IJ, Lin YC, Chen JS, Fang SY. A $2.6 \mathrm{Mb}$ interval on chromosome 6q25.2-q25.3 is commonly deleted in human nasal natural killer/T-cell lymphoma. Br J Hematol. 2003;122:590-9.

56. Ho FCS, Todd D, Loke SL, Ng RP, Khoo RKK. Clinicopathological features of malignant lymphomas in 294 Hong Kong Chinese patients, retrospective study covering an eight year period. Int J Cancer. 1984;34:143-8.

57. Chan JK, Ng CS, Lau WH, Lo STH. Most nasal/ nasopharyngeal lymphomas are peripheral T-cell lymphomas. Am J Surg Pathol. 1987;11:418-29.

58. Ho FC, Choy D, Loke SL, Kung ITM, Fu KH, Liang R, et al. Polymorphic reticulosis and conventional lymphomas of the nose and apper aerodigestive tract: a clinicopathologic study of 70 cases, and immunophenotypic studies of 16 cases. Hum Pathol. 1990;21:1041-50.

59. Aozasa K, Watanabe Y, Ikeda H. Malignant histiocytosis presenting as lethal midline granuloma. Path Res Pract. 1981;171:314-24.

60. Aozasa K, Inoue A. Malignant histiocytosis presenting as lethal midline graanuloma: Immunohistological study. J Pathol. 1982;138:241-9.

61. Aozasa K, Ohsawa M, Tajima K, Sasaki R, Maeda H, Matsunaga $\mathrm{T}$, et al. Nation-wide study of lethal midline granuloma in Japan: Frequencies of Wegener's granulomatosis, polymorphic reticulosis, malignant lymphoma and other related conditions. Int $\mathbf{J}$ Cancer. 1989;44:63-6.

62. Aozasa K, Yang WI, Lee YB, Pan WS, Wu YF, Horiuchi K, et al. Lethal midline granuloma in Seoul (Korea) and Shanghai (China). Int J Cancer. 1992;52:673-4 (Letter to the Editor).
63. Kojya S, Itokazu T, Maeshiro N, Esu H, Noda Y, Mishima K, et al. Lethal midline granuloma in Okinawa with special emphasis on polymorphic reticulosis. Jpn J Cancer Res. 1994;85:384-8.

64. Gaal K, Sun NCJ, Hernandez AM, Arber DA. Sinonasal NK/Tcell lymphomas in the United States. Am J Surg Pathol. 2000; 24:1511-7.

65. Rudiger T, Weisenburger DD, Anderson JR, Armitage JO, Diebold J, MacLennan KA, et al. Peripheral T-cell lymphoma (excluding anaplastic large-cell lymphoma): results from the Non-Hodgkin's Lymphoma Classification Project. Ann Oncol. 2002;13:140-9.

66. Arber DA, Weiss LM, Albujor PF, Chen YY, Jaffe ES. Nasal lymphoma in Peru. High inicidencce of T-cell immunophenotype and Epstein-Barr virus infection. Am J Surg Pathol. 1993;17:392-9.

67. Hardjolukito E, Kurniawan AN, Kodairiah R, Ham MF, Luo WJ, Nakatsuka S, et al. Sinonasal lymphomas in Indonesia: Immunophenotype and Epstein-Barr virus association. Med J Indonesia. 2004;13:71-6.

68. Ohsawa M, Shingu N, Inohara H, Kubo T, Yang WI, Yoon JH, et al. Chronological changes in incidences of polymorphic reticulosis in Korea and Japan. Oncol. 1999;56:202-7.

69. Kojya S, Matsumura J, Li T, Hongvo T, Inazawa J, Kirihata M, et al. Familial nasal NK/T-cell lymphoma and icide use. Am J Hematol. 2001;66:145-7.

70. Zahm SH, Blair A. Pesticides and non-Hodgkin's lymphoma. Cancer Res. 1992;52(Suppl):5485-8.

71. Waterhouse D, Carman WJ, Schottenfeld D, Gridley G, Mclean S. Cancer incidence in the rural community of Tecumseh, Michigan: A pattern of increased lymphopoietic neoplasms. Cancer. 1996;77:763-70.

72. Hardell L, Erickson MA. A case-control study of non-Hodgkin's lymphoma and exposure to pesticide. Cancer. 1999;85:1353-60.

73. Xu JX, Hoshida Y, Yang WI, Inohara H, Kubo T, Kim GW, et al. Life-style and environmental factors in the development of nasal NK/T-cell lymphoma: A case-control study in East Asia. Int J Cancer. 2006;120:406-10.

74. Miligi L, Costantini AS, Bolejack V, Varaldi A, Benvenuti A, Nanni $\mathrm{O}$, et al. Non-Hodgkin's lymphoma, leukemia, and exposure in agriculture: results from the Italian multicenter casecontrol study. Am J Ind Med. 2003;44:627-36.

75. Chiu BCH, Dave BJ, Blair A, Gapstur SM, Zahm SH, Weisenburger DD. Agricultural pesticide use and risk of $\mathrm{t}(14 ; 18)$-defined subtypes of non-Hodgkin lymphoma. Blood. 2006;108:1363-9. 